\section{B.D.H. Medical Products}

Amons the pamphlets recently received from the British Drug Houses, Ltd., London, N.1, is a series describing their vitamin products, Radiostol, Radiostoleum and Radio.Malt. It is pointed out that the proof that pure vitamin D (calciferol) cures human rickets has recently been furnished by the work of J. C. Spence (Lancet, 911, Oct. 21, 1933). 'This investigation forms the concluding chapter of the series, which began with the discovery of vitamin D, and includes the discovery of the effect of ultraviolet light upon ergosterol and the final isolation of the vitamin in the pure state. Another compound which has recently found a use in clinical medicine is glycine or amino-acetic acid. It is employed in large doses by the mouth in certain diseases of the muscles, since there is evidence of a disturbance of the metabolism of creatine and creatinine in these conditions, and it is now known that creatine plays an important part in muscular contraction in the form of phosphagen or creatine-phosphoric acid. Glycine B.D.H. is a white crystalline substance with a sweetish taste readily soluble in water; up to $30 \mathrm{gm}$. can be taken daily with safety. In some of these cases greater improvement is observed if ephedrine is also given.

\section{International Congress on Alcoholism}

THE twentieth International Congress on Alcoholism will be held at the Imperial Institute, South Kensing. ton, S.W.7, under the presidency of Lord Astor on July 30-August 3, when the following papers among others will be read: "Licensing Legislation in Europe", by Dr. R. Hercod of Lausanne; "Legislation on Inebriety", by Dr. E. Gabriel of Vienna; "Alcohol Consumption and Specific Male Mortality", by Dr. R. Bandel of Nuremberg; "Alcohol in the Treatment of Disease", by Dr. J. D. Rolleston of London; "Alcohol and Eugenics", by Prof. H. Gachot of Strasbourg; "The Causes and Treatment of Inebriety", by Dr. A. E. Carver of Caldecote Hall ; "The Toxicological Aspects of Alcohol and Drug Addiction", by Sir William Willcox of London ; and "The Teaching of Hygiene in Schools", by Sir George Newman. The Congress will be attended by representatives of the following Governments : Austria, Denmark, Finland, France, Mexico, Poland, U.S.S.R., and Switzerland. Membership tickets, price 10s., can be obtained from the Secretariat, Room H, Imperial Institute, South Kensington.

\section{Announcements}

Mr. W. F. Hurton has been awarded the Armourers and Brasiers' Company's research fellowship in aeronautics. Mr. Hilton will carry out his research work at the Imperial College of Seience and Technology, London.

IT is announced that the library of the Geological Survey will be closed on July 23 during transfer to the new Museum at South Kensington. It is expected that it will not be reopened for two months. During the interim, members of the public who wish to consult the published Geological Survey maps and memoirs may do so at the Library of the Geological Society, Burlington House, Piccadilly, W.1.

AT the invitation of the Council of the Pharmaceutical Society of Northern Ireland, the British Pharmaceutical Conference will be held in 1935 in Belfast. The following officers have been elected: Chairman, Dr. F. W. Crossley-Holland ; Treasurer, Mr. T. E. Lescher; General Secretaries, Mr. C. E. Corfield and Mr. G. R. Boyes.

A scientrfic society for the study of anæsthesia was founded last month in Paris on the initiative of Dr. Robert Monod. The society, the number of whose members will be limited to 100 , has already admitted 6 chemists, 6 physicians, 30 surgeons, 6 otorhinolaryngologists, 5 physiologists, 2 neurologists, 2 obstetricians, 2 stomatologists and 1 physicist from France, Belgium, Italy and Switzerland.

Ar a meeting of the Indian Association for the Cultivation of Science held in Calcutta on June 19, Sir Nitratan Sircar, consulting physician, and formerly vice-chancellor of the University of Calcutta, was elected president in place of Sir C. V. Raman, and a new committee of management was appointed. At the same meeting, Mr. J. N. Basu, Dr. Birbal Sahani, Dr. Ganesh Prashad, Dr. Bimala C. Law and Dr. J. N. Mukerji were elected vice-presidents ; and Dr. S. K. Mitra was appointed secretary in place of Dr. K. S. Krishnan.

Applications are invited for the following appointments, on or before the dates mentioned :-A lecturer in mechanical engineering at the Municipal Technical College, Hull--The Director of Education, Education Offices, Guildhall, Hull (Aug. 1). A lecturer in applied mathematics at the United College, University of St. Andrews-The Secretary (Aug. 1). Two chemists at the Royal Gunpowder Factory, Waltham AbbeyThe Principal Clerk, Central Office, Royal Gunpowder and Small Arms Factories, Enfield Lock, Middlesex (Aug. 4). A headmaster of Middle Street Central Technical School, Newcastle-upon-Tyne-The Director of Education, Education Office, Northumberland Road, Newcastle-upon-Tyne (Aug. 4). A lecturer in physics at the Norwich Technical College -The Principal, Norwich Technical College, St. George Street, Norwich (Aug. 4). A principal of the Carlisle Technical School-The Director of Education, Education Offices, 19, Fisher Street, Carlisle (Aug. 8). An aircraft inspector in the Civil Aviation Directorate of the Government of India-The High Commissioner for India, General Department, India House, Aldwych, London, W.C.2 (Aug. 11). An assistant organiser of agricultural education for West Suffolk -The Chief Agricultural Officer, West Suffolk, Shire Hall, Bury St. Edmunds (Aug. 11). A reader in industrial hygiene and medicine in the University of Birmingham--The Secretary (Sept. 1). An assistant lecturer in biochemistry in the University of Birmingham-The Secretary (Sept. 1). A temporary demonstrator in botany in the University of Leeds-The Registrar (Sept. 17). 